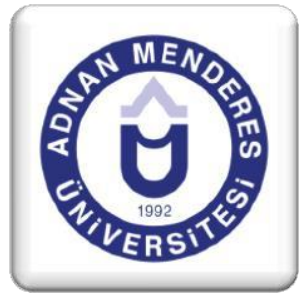

\section{STEM Uygulamaları Öğretmen Öz-yeterlik Ölçeğinin Geliştirilmesi: Bir Geçerlik ve Güvenirlik Çalışması}

\author{
Cemre YAMAN ${ }^{1}$, Adem ÖZDEMIR $^{2}$, RukenAKAR \\ VURAL $^{3}$
}

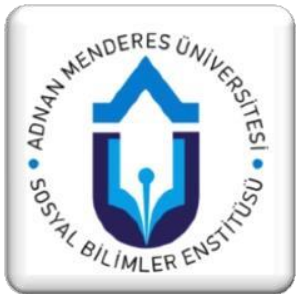

\title{
ÖZET
}

$\mathrm{Bu}$ çalışmanın amacı, STEM yaklaşımı ile ilgili STEM Uygulamaları Öğretmen Özyeterlik Ölçeği'ni geliştirmektir. Bu nedenle, çalışma için 55 maddelik bir STEM Uygulamaları Öğretmen Özyeterlik Ölçeği soru havuzu hazırlanmıştır. Hazırlanan ölçek maddeleri Türkiye'nin batı bölgesinde bulunan bir kamu üniversitesinin eğitim fakültesinde öğrenim görmekte olan 219 öğretmen adayına uygulanmış, geçerlik ve güvenirlik çalışmaları yapılmıştır. Ölçeğin Cronbach's Alpha iç tutarlık katsayıs1 .97 olarak hesaplanmıştır. Ölçek tek boyutlu olup, toplam varyansın \% 68.2'sini açıklamaktadır. Yapılan analizler sonucunda STEM Uygulamaları Öğretmen Özyeterlik Ölçeği 55 maddeden 18 maddeye düşürülmüştür. Doğrulayıcı faktör analizi sonuçlarına göre ölçeğin tek faktörlü yapısına ait uyum indeksleri oldukça iyi düzeydedir $(\mathrm{RMSEA}=.05, \mathrm{NFI}=.99, \mathrm{CFI}=1.00, \mathrm{IFI}=1.00$, $\mathrm{RFI}=.98, \mathrm{GFI}=.90$ ve SRMR= .025). Ayrıca geçerliğe katkı sağlamak için de STEM eğitim programına katılan ve katılmayan, STEM hakkında bilgisi olan ve olmayan öğrencilerin STEM özyeterlik puanları karşılaştırılmıştır. Yapılan analizler sonucunda STEM hakkında bilgisi olan öğrenciler ve STEM etkinliği yapan öğrenciler lehine anlamlı farklar bulunmuştur.

Anahtar Kelimeler: STEM, Özyeterlik, Geçerlik, Güvenirlik, Fen Eğitimi.

\section{Development of the Teacher Self-Efficacy Scale for STEM Practices: A Validity and Reliability Study}

\begin{abstract}
The purpose of this study is to develop A Teacher Self-Efficacy Scale for STEM Practices. For this aim, a question pool consisted of 55-item was prepared for the study. The preliminary form was applied to 219 prospective teachers studying in the faculty of education at a public university which is located in the western region of Turkey. Validity and reliability studies have been done and Cronbach's Alpha internal consistency coefficient was calculated as .97. The scale is one-dimensional and reveals $68.2 \%$ of the total variance. As a result of these analyzes, the Teacher Self-Efficacy Scale for STEM Practices was reduced from 55 to 18 items. According to the confirmatory factor analysis results, the fit index of the one-factor scale is quite satisfactory $(\mathrm{RMSEA}=.05, \mathrm{NFI}=.99, \mathrm{CFI}=1.00, \mathrm{IFI}=1.00, \mathrm{RFI}=.98, \mathrm{GFI}=.90$ and $\mathrm{SRMR}=.025)$. At the last phase of the study, Scale self-efficacy scores of the prospective teacher who are having and not having STEM knowledge already were compared as well. As a result, significant differences were found in favor of students who are already having STEM knowledge.
\end{abstract}

Keywords: STEM, Self- efficacy, Validity, Reliability, Science Education.

\footnotetext{
${ }^{1}$ Adnan Menderes Üniversitesi Eğitim Fakültesi, Matematik ve Fen Bilimleri Eğitimi Bölümü, Fen Bilgisi Eğitimi ABD, cemreyaman1995@gmail.com

${ }^{2}$ Adnan Menderes Üniversitesi Eğitim Fakültesi, Matematik ve Fen Bilimleri Eğitimi Bölümü, Fen Bilgisi Eğitimi ABD, ademozdemir@adu.edu.tr

${ }^{3}$ Adnan Menderes Üniversitesi Eğitim Fakültesi, Eğitim Bilimleri Bölümü, Eğitim Programları ve Öğretim ABD, rakarvural@adu.edu.tr
} 


\section{Giris}

Evrenselleşme sonucu tüm dünyada bilim ve teknoloji alanlarındaki rekabet her geçen gün daha da artmaktadır. Dünyada yaşanan bu değişim, yenileşme çabalarını da artmış̧ır (Akgündüz, Aydeniz, Çakmakçı, Çavaş, Çorlu, Öner ve Özdemir, 2015). Yaşanan bilimsel ve teknolojik gelişmeler sonucu hızlanan liderlik yarışıyla birlikte ülkeler eğitim sistemlerinde yenilik yapma yoluna gitmiştir (Akgündüz vd., 2015). Bilgiye dayalı bir toplum bilim ve teknolojinin kullanılmasına dayanmaktadır (Tunç, 2018). Bilgi toplumu ise bireylerin bilgiye fen, teknoloji, mühendislik ve matematiği kullanarak ulaşması ve bu kavramları günlük yaşamla ilişkilendirmesiyle oluşturulur. Bu nedenle ülkemizde verilen Fen Bilgisi eğitimine STEM (Fen, Teknoloji, Mühendislik, Matematik) yaklaşımı entegre edilmiştir.

STEM yaklaşımı, Fen Bilimleri öğretim programında belirtilen bilgi, beceri, algı ve değerleri bireye kazandırmanın yanı sıra Fen alanındaki mesleki bilincin gelişmesinde de oldukça etkilidir (Gencer, 2015). 2017 yılında yayınlanan ve 2018 yılında güncellenen Fen Bilimleri öğretim programına bakıldığında (MEB, 2018) bilim, mühendislik ve matematiğin programa dahil edildiği dikkati çekmektedir.

STEM eğitimi, öğrencilerin herhangi bir problemle karşılaştı̆̆ında kendi bilgilerini ve anlam üretme süreçlerini kullanarak, problemi anlamalarını, çözüm üretmelerini ve bu becerilerini geliştirerek kalıcı öğrenmelere ulaşmalarını sağlamaktadır (Wang, 2012). Bu nedenle, öğrencilerde anlamlı ve kalıcı öğrenmeler yapılandırabilmek amacıyla Fen Bilimleri dersi içerik birimlerinin bir kısmının STEM yaklaşımı kullanılarak tasarlanması önerilmektedir.

STEM terimi ilk defa 2001 yılında Dr. Rahmaley tarafından kullanılmıştır. STEM; Science, Technology, Engineering ve Mathematics kelimelerinin baş harflerinden oluşmaktadır. $\mathrm{Bu}$ kavramlar ise birbiriyle etkileşim halindedir. STEM yaklaşımı farklı disiplinleri bir araya getirmektedir. Bir araya gelen bu disiplinler, bireye çok boyutlu öğrenme sağlamaktadır. Bu eğitim sonucunda birey tüm bilgileri bütünleştirerek harmanlanmış bir bilgi ve anlam yapısı elde edebilmektedir (Yıldırım, 2017). STEM, disiplinler arası bir yaklaşım olup, bireylerin eleştirel düşünme, analitik düşünme ve disiplinlerarası akıl yürütme becerilerini de artırabilmektedir. STEM yaklaşımı bireylerin problem çözme becerilerine odaklı bir yaklaşımdır. Aynı zamanda bu yaklaşım kullanılarak bireye işbirlikli öğrenme ve eleştirel düşünme becerileri de kazandırılabilmektedir. Bu beceriler yaşadığımız yüzyılın gelişen bilim ve teknolojisine ayak uydurabilmek için gereken becerilerdir (Aydeniz, 2017). STEM yaklaşımı aynı zamanda bireylerin günlük yaşamlarında problem çözme becerilerini de geliştirir.

STEM yaklaşımı bugün pek çok ülkenin eğitim sisteminde önemli bir yer tutmaktadır. Özellikle ABD, STEM yaklaşımına oldukça önem vermektedir. ABD başkanı STEM eğitiminin çok önemli bir konu olduğunu defalarca vurgulamıştır (Akgündüz vd., 2015). ABD'de STEM yaklaşımı eğitim programına oldukça başarılı bir şekilde entegre edilmiştir. Türkiye'de ise Fen Bilimleri öğretim programına kısmen uyarlanan STEM yaklaşımı, çoğu üniversitenin Fen Bilgisi Öğretmenliği anabilim dalı eğitim programında bulunan Özel Öğretim Yöntemleri dersinde derinlemesine ele alınmaktadır (Özçelik ve Akgündüz, 2017, Eroğlu ve Bektaş, 2016). STEM yaklaşımı ülkemizdeki eğitim fakültelerinde ele alınmaya başlanmıştır ve öğretmen adaylarının edindikleri STEM becerilerini öğretmenlik deneyimlerinde kullanmaları beklenmektedir.

STEM yaklaşımının amaçları şöyle özetlenebilir (Thomas, 2014):

1. Bilimsel ve teknolojik okuryazarlığı artırmak, 
2. Bireye problem çözme ve eleştirel düşünme becerisi kazandırmak,

3. Teknolojiye ve mühendisliğe olan farkındalığı artırmak,

4. Mühendislik kariyerine olan ilgiyi artırmak,

5. Ü̈lkeler için ekonomik kazanç sağlanabilecek yenilikler üretmek.

Yukarıdaki maddelere bakıldığında STEM yaklaşımı için, çağın bilimsel ve teknolojik gelişmelerine ayak uydurmak ve ülkelere ekonomik kazanç sağlayacak yenilikler üretmek oldukça önemlidir. Bu nedenle yeni nesil mühendisler yetiştirmek için STEM yaklaşımını kullanmak ve bu yaklaşımı eğitim programlarına uyarlamak gerekmektedir. Ayrıca bilim ve teknoloji alanlarındaki boşluklar STEM eğitimi almış olan bu bireylerle dolar (Eroğlu ve Bektaş, 2016). STEM eğitimi almış olan bireyler, bilgiyi daha çabuk kavrar. Bilgiyi mühendislik, teknoloji, matematik ve fen bilimlerine uyarlar. Böylece yeni tasarımlar elde ederler. Bu beceriler, öğrencinin analitik düşünme, disiplinler arası sentez yapma yeteneğini de geliştirmektedir.

Ülkemizdeki lisans düzeyinde Fen Bilgisi eğitim programına bakıldığında STEM yaklaşımının henüz yeterince bu programa entegre edildiği söylenemez. Bu yüzden ülkemizde STEM alanlarına yerleşme sayılarına bakıldığında son yıllarda düşüş olduğu gözlemlenmiştir. $\mathrm{Bu}$ durum ise STEM yaklaşımı konusunda ülkemizde tedbirler alınması gerektiğini göstermektedir (Yıldııı, 2017). STEM yaklaşımı Fen Bilgisi eğitim programına ne kadar fazla entegre edilirse, gelecek nesle o kadar fazla STEM bilgisi verilir.

Ülkemizde STEM'in etkili şekilde uygulanabilmesi için, öğretmenlere ve öğretmen adaylarına STEM yaklaşımıyla ilgili gerekli bilgilerin doğru ve eksiksiz olarak verilmesi gerekmektedir. Böylece öğretmen ve öğretmen adayları, STEM yaklaşımını Fen Bilgisi derslerine doğru olarak yansitacak ve öğrenciler de bu sayede problem çözme ve eleştirel düşünme becerilerini kazanacaklardır. Bunun sonucunda ise öğrenciler ve öğretmenler yukarıda verilen STEM yaklaşımının amaçlarına ulaşmış olacaklardır.

Son dönemlerde STEM yaklaşımıyla ilgili araştırmalar diğer ülkelerin yanı sıra Türkiye'de de hız kazanmıştır. Birçok araştırmacı STEM konusunu araştırmakta, bu konuyla ilgili makale, rapor ve bildiri yayınlamaktadır. Ancak bu yapılan araştırmalara bakıldığında hedef kitlenin ilköğretim öğrencileri olduğu görülmektedir. STEM ile ilgili özyeterlik çalışmasına ülkemizde rastlanamamıştır.

Sosyal Öğrenme kuramıyla birlikte kullanılan özyeterlik algısı ilk olarak Bandura (1977) tarafından ortaya atılmış ve araştırmacılar tarafından büyük ilgi görmüştür (Dolapci, 2013). Özyeterlik algısı pek çok çalışmada ele alınmıştır ve hala çalışmalarda kullanılmaktadır.

Özyeterlik, Sosyal Öğrenme Kuramı'nın önemli parametrelerinden biridir. Özyeterlik çalışmalarıyla bilinen Bandura (1997) özyeterliği, bireyin herhangi bir konudaki performansını göstermek için gerekli adımları belirleyip, bu adımları uygulama kapasitesi olarak belirtmektedir. Bireyin bir problemi başarma ya da başaramama düşüncesi bireyin özyeterlik algısını etkilemektedir. Bandura (1977), özyeterlik algısının 4 maddeden oluştuğunu belirtmiştir. Bu maddeler;

1. Bireyin geçmişteki deneyimlerinden etkilenmesi,

2. Bireyin başka bireylerin deneyimlerinden etkilenmesi,

3. Bireyin başaracağına ya da başaramayacağına dair ikna edilmesi,

4. Bireyin içinde bulunduğu duygusal durum olarak sıralanabilir. 
Pajares'e (1996) göre özyeterlik inancının oluşumu ve kullanılması duyusal bir süreçtir. Bireyin çözdüğü bir problemin sonucuyla ilgili yorumu bu probleme benzer bir başka problem için kullanılmaktadır (Dolapci, 2013). Bir başka deyişle, herhangi bir problemin sonuçlandırılması, o problemin bir başka zaman da başarıyla çözümlenmesine katkı sağlayacaktır. Bu nedenle bireylerin kendi yetenekleriyle ilgili geliştirdikleri özyeterlikleri ileride neler yapabileceklerini seçmede etkili olacaktır.

Özyeterlik kavramı, öğretmen adayları için genellikle lisans öğretim programlarında yer alan bilgi, beceri ve okul uygulamalarında ele alınmaktadır (Yüksel, 2010). Öğretmen adaylarının eğitim gördükleri süreçte karşılaştıkları herhangi bir yetersizlik, meslek hayatlarına başladıklarında kaygı, stres ve endişe olarak geri dönecektir. Bu yüzden öğretmen adaylarının meslek hayatlarında sıkıntı yaşamamaları için kendilerini meslekte yeterli hissedecek şekilde mezun edilmeleri gerekmektedir.

Özyeterlik algıları yüksek olan öğretmen adayları meslek hayatlarında farklı yöntem ve yaklaşımları uygulamaya eğilimlidirler. Özyeterlik algıları düşük olan öğretmen adayları ise mesleğe başladıklarında sınıflarında genellikle öğretmen merkezli ders işlemektedirler (Akkoyunlu, Feza ve Aysun, 2005). Alanyazın incelendiğinde özyeterlikleri yüksek olan öğretmen adaylarının sınıflarında öğrenci merkezli ders işledikleri, öğrencilerinin başarılı olmaları için daha fazla çaba harcadıkları gözlemlenmektedir (Gürol, Altunbaş ve Karaaslan, 2010). Bu yüzden eğitim fakültelerinin lisans programlarında öğretmen adaylarının özyeterliklerini geliştirecek eğitimler yoğunlaştırılmalıdır.

Psikoloji ve Sosyoloji alanları için geliştirilmiş olan özyeterlik, daha sonra pek çok alana uyarlanmıştır (Seferoğlu ve Akbıyık, 2005). Literatür incelendiğinde özyeterlikle ilgili pek çok farklı çalışmaya ulaşılmıştır. Fakat Türkiye'de STEM özyeterliğine dair herhangi bir çalışmaya rastlanamamıştır. Ayrıca Fen Bilimleri dersi öğretim programına bakıldığında (MEB, 2018), öğrencilere kazandırılacak beceriler arasında fen, matematik, teknoloji ve mühendislik olduğu görülmektedir. $\mathrm{Bu}$ becerileri ise öğrencilere öğretmenler kazandıracaktır. Söz konusu bu becerilerin kazandırılabilmesi için öğretmenlerin STEM yaklaşımı konusunda yeterli olmaları gerekmektedir. Bu nedenle, geleceğin öğretmenlerinin özyeterliklerini ölçmek amacıyla bu çalışma yapılmıştır.

\subsection{Araştırmanın Amacı}

Bu araştırmanın temel amacı, öğretmen ve öğretmen adaylarının STEM yaklaşımıyla ilgili özyeterlik düzeylerini belirlemek için STEM Uygulamaları Öğretmen Özyeterlik Ölçeği geliştirmektir. Ölçeğin, özyeterlik çalışmalarında araştırmacılara veri toplama aracı olarak kaynak oluşturacağı düşünülmektedir.

\section{Yöntem}

$\mathrm{Bu}$ başlık altında araştırma modeli, çalışma grubu, STEM Uygulamaları Öğretmen Özyeterlik Ölçeği ve yapılan işlemlere yer verilmiştir.

\subsection{Araştırma Modeli}

Bu çalışma Türkiye'nin Ege Bölgesi'nde bulunan bir üniversitenin Eğitim Fakültesi'nde öğrenim görmekte olan öğretmen adaylarının STEM özyeterliklerini ölçmek için geliştirilen bir ölçme aracının geçerlik ve güvenirlik çalışmasını yapmaktır.

Araştırmada STEM Uygulamaları Öğretmen Özyeterlik Ölçeği nin geçerlik çalışması için yap1 geçerliği incelenmiştir. Özyeterlik ölçeğinin yap1 geçerliği için Açımlayıc1 Faktör Analizi (AFA) ve Doğrulayıcı Faktör Analizi (DFA) yapılmıştır. Açımlayıcı Faktör Analizi'nde değişkenler arasındaki ilişki göz önünde bulundurulur ve bu ilişkilerden yola 
çıkılarak faktör bulunur ve teori üretilir. Doğrulayıcı Faktör Analizi'nde ise değişkenler arasındaki önceden saptanmış bir ilişkinin test edilmesi söz konusudur (Büyüköztürk, 2002). Geçerliğe katkıda bulunması amacıyla STEM etkinliğine katılan ve katılmayan, STEM hakkında detaylı bilgisi olan ve olmayan öğrencilerin özyeterlik puanları da karşılaştırılmıştır.

Bu çalı̧̧ma Türkiye'nin Ege Bölgesi'nde bulunan bir üniversitenin eğitim fakültesinde öğrenim gören 219 öğretmen adayılla yürütülmüştür. Çalışma grubu ise uygun örnekleme yöntemiyle seçilmiştir. Uygun örnekleme yöntemi; araştırmacının kolaylıkla ulaşabileceği örneklemi seçmesi yöntemidir (Özen ve Gül, 2007).

\section{2. Çalıșma Grubu}

Araştırmanın çalışma grubunu 2017-2018 Bahar yarıyılında Türkiye'nin Ege Bölgesi'nde bulunan bir üniversitenin Eğitim Fakültesi’nde öğrenim görmekte olan 219 öğretmen adayı oluşturmuştur. Araştırmanın çalışma grubuna ilişkin bilgiler, Çizelge 1.'de yer almaktadır. Çalışmaya katılan öğretmen adaylarının 47'si (\% 21.46) 2. Sınıf, 77'si (\% 35.15) 3. Sınıf, 74 'ü (\% 33.79) 4. Sinıf ve 21'i (\% 9.59) pedagojik formasyon programı öğrencisidir. Bu çalışma, ampirik olarak verinin yapısını ortaya koymayı amaçlayan yeni bir çalışma olduğu için, doğrulayıcı ve açımlayıcı faktör analizi aynı örneklem üzerinde gerçekleştirilmiştir.

Çizelge 1. Çalışma grubu özellikleri.

\begin{tabular}{cccclc}
\hline Anabilim Dalı & 2. sinıf & 3. sinıf & 4. sinıf & $\begin{array}{l}\text { Pedagojik } \\
\text { Formasyon }\end{array}$ & Toplam \\
& & & & & \\
\hline Fen Bilgisi & 9 & 46 & 52 & 0 & 107 \\
Matematik & 35 & 8 & 20 & 21 & 83 \\
BÖTE & 3 & 23 & 2 & 0 & 29 \\
Toplam & 47 & 77 & 74 & 21 & 219 \\
\hline
\end{tabular}

\subsection{STEM Uygulamaları Öğretmen Özyeterlik Ölçeği}

Fen Eğitimi STEM Uygulamaları Öğretmen Özyeterlik Ölçeği, Fen Bilgisi öğretmen ve öğretmen adaylarının STEM yaklaşımı özyeterliklerinin belirlenmesine yönelik hazırlanmıştır. Bu nedenle 55 maddelik bir madde havuzu oluşturulmuştur. Bu ölçek 5'li likert tipine göre hazırlanmış olup, "Hiçbir Zaman (1), Nadiren (2), Bazen (3), Sık Sık (4) ve Her Zaman (5)" olarak derecelendirilmiştir. Bu işlemlerden sonra ise geçerlik ve güvenirlik analizi yapılmıştır.

Ölçeğin geçerlik çalışması için yap1 geçerliğine bakılmıştır. Ölçeğin yap1 geçerliği için açımlayıcı faktör analizi (AFA) yapılmıştır. Verilerin faktör analizine uygunluğunu kontrol etmek için ise KMO katsayısı ve Barlett's Sphericity test sonucuna bakılmıştır. Geçerlik analizlerinden sonra yapılan düzeltmeler sonucunda ölçek tek boyutlu 18 maddeye düşürülmüştür. Güvenirliği hesaplamak için ise Cronbach's Alpha iç tutarlık katsayısına bakılmıştır. Ölçeğin faktör yapısının doğrulanması amacıyla doğrulayıcı faktör analizi (DFA) yapılmıştır. 


\section{4. İșlemler}

Ölçeğin geçerliği yapı geçerliği ile hesaplanmıştır. Yapı geçerliğine bakılabilmesi için Fen Bilgisi, Matematik ve BÖTE 2., 3., 4. ve formasyon sınıflarında öğrenim görmekte olan 219 öğrenciye araştırmacı tarafından hazırlanan STEM Uygulamaları Öğretmen Özyeterlik Ölçeği uygulanmıştır. Ölçeğin yapı geçerliği için Açımlayıcı Faktör Analizi (AFA) kullanılarak ölçeğin yapısı incelenmiştir. Güvenirlik çalışması için ise Cronbach's Alpha, Gutman Split-Half ve Spearman-Brown katsayılarına bakılmıştır. AFA için verilerin doğrulanabilmesi amacıyla Doğrulayıcı Faktör Analizi (DFA) yapılmıştır.

\section{Bulgular}

STEM Uygulamaları Öğretmen Özyeterlik Ölçeği 'nin faktör analizi için Temel Bileşenler Analizi kullanılmıştır. Analize başlanmadan önce 55 madde için toplanan verinin faktör analizine uygunluğuna (örneklem büyüklüğü) ve verilerin normal dağılıma uygunluğuna bakılmıştır. Verilerin faktör analizine uygunluğu için KMO .60'tan yüksek, Barlett testinin ise anlamlı çıkması gerekmektedir (Büyüköztürk, 2004). Bu çalışmada 55 madde için KMO örneklem uygunluk katsayıs1 .96, Barlett Sphericity testi değeri ise $10592.36(\mathrm{p}=.000)$ bulunmuştur. Her maddenin faktör analizine uygun olup olmadığına karar vermek için ise Anti-Image korelasyon değerinin .50 'den büyük olan maddelerin faktör analizine dahil edilmesine karar verilmiştir (Sipahi, Yurtkoru ve Çinko, 2008). Sonuçlara bakıldığında ölçek üzerinde faktör analizi yapılabileceği görülmektedir.

\subsection{Faktör Analizi ile İlgili Bulgular}

Ölçeğin yapı geçerliği için ilk önce faktör analizine bakılmaktadır. Faktör analizi ise birden fazla değişkene ait bir yapının bulunması için kullanılır (Ergin, 1995). Varimax döndürmeli faktör analizi sonuçlarına göre farklı faktörlerde yüksek yüdeğerine sahip olmasına rağmen binişik olduğu için $1,2,3,4,7,8,9,10,12,13,15,18,19,20,21,22,23,24,26,27,28,29$, 30, 31, 34, 36, 37, 38, 39, 40, 42, 43, 49, 51, 52, 54 ve 55. maddeler ölçekten çıkarılmıştır. $\mathrm{Bu}$ maddeler ölçekten çıkarıldıktan sonra kalan 18 maddenin KMO değeri .98, Barlett Sphericity test değeri ise $3614.14(\mathrm{p}=.000)$ olarak hesaplanmıştır. Faktör analizi sonucunda tek boyutlu bir ölçek elde edilmiştir. Yük değeri .30'un altındaki maddelerin testten çıkarılması gerekmektedir. Hazırlanan bu ölçeğin faktör yük değerleri .77-.86 arasında değişmektedir. Faktör yük değeri maddelerin faktörlerle olan ilişkisini açıklar (Büyüköztürk, 2002). Ortak varyansın .50'den büyük olmasına dikkat edilmiştir (Nakip, 2003). En küçük ortak varyans ise .59 olarak hesaplanmıştır. Cronbach's Alpha iç tutarlık katsayısı .97 ve tek boyutlu yap1 olup toplam varyansın \% 68.2'sini açıklamaktadır. Çizelge 2'de ortak varyanslar, anti imaj korelasyon katsayıları, faktör yükleri ve maddeler verilmiştir. Ölçek için hesaplanan Gutman Split-Half ve Spearman-Brown katsayıları iyi düzeyde olup ikisi de .96 olarak hesaplanmıştır. 
Çizelge 2. STEM Uygulamaları Öğretmen Özyeterlik Ölçeği betimsel istatistikleri.

\begin{tabular}{|c|c|c|c|c|c|}
\hline $\begin{array}{l}\text { Madde } \\
\text { No* }\end{array}$ & Madde & $\mathbf{N}$ & $\begin{array}{c}\text { Ortak } \\
\text { Varyans }\end{array}$ & $\begin{array}{l}\text { Anti } \\
\text { İmaj }\end{array}$ & $\begin{array}{c}\text { Faktör } \\
\text { Yükü }\end{array}$ \\
\hline $1(5)$ & $\begin{array}{l}\text { STEM yaklaşımına özgün sonuçlara } \\
\text { ulaşabilirim. }\end{array}$ & 219 & .66 & .98 & .86 \\
\hline $2(6)$ & $\begin{array}{l}\text { STEM etkinliği tasarlarken gerekli olan } \\
\text { bilimsel süreç becerileri konusunda akademik } \\
\text { olarak yeterliyim. }\end{array}$ & 219 & .70 & .98 & .85 \\
\hline $3(11)$ & $\begin{array}{l}\text { STEM uygulamalarında kullanılmak üzere } \\
\text { modeller ve materyaller geliştirebilirim. }\end{array}$ & 219 & .69 & .98 & .85 \\
\hline $4(14)$ & $\begin{array}{l}\begin{array}{l}\text { STEM ile ilgili } \\
\text { tasarlayabilirim. }\end{array}\end{array}$ & 219 & .73 & .98 & .85 \\
\hline $5(16)$ & $\begin{array}{l}\text { STEM ile ilgili etkinliklerin sonuçlarını } \\
\text { rahatça yorumlayabilirim. }\end{array}$ & 219 & .72 & .97 & .85 \\
\hline $6(17)$ & $\begin{array}{l}\text { STEM uygulamalarıyla ilgili projelerde görev } \\
\text { alabilecek düzeydeyim. }\end{array}$ & 219 & .73 & .98 & .84 \\
\hline $7(25)$ & $\begin{array}{l}\text { Öğrencilerin STEM ile ilgili sorularını } \\
\text { yantlayabilirim. }\end{array}$ & 219 & .62 & .99 & .84 \\
\hline $8(32)$ & $\begin{array}{l}\text { STEM etkinliklerini günlük hayata } \\
\text { uyarlayabilirim. }\end{array}$ & 219 & .72 & .97 & .84 \\
\hline $9(33)$ & $\begin{array}{l}\text { Zeka alanını geliştirici STEM etkinlikleri } \\
\text { tasarlayabilirim. }\end{array}$ & 219 & .69 & .98 & .84 \\
\hline $10(35)$ & $\begin{array}{l}\text { STEM etkinliklerinde kazandırılması gereken } \\
\text { hedefleri öğrenci ve çevre özelliklerine uygun } \\
\text { olarak belirleyebilirim. }\end{array}$ & 219 & .62 & .98 & .83 \\
\hline $11(41)$ & $\begin{array}{l}\text { Bir STEM etkinliği yapmaya } \\
\text { verdiğimde hemen işe girişirim. }\end{array}$ & 219 & .60 & .98 & .83 \\
\hline $12(44)$ & $\begin{array}{l}\text { STEM uygulamalarında kendimi yeterli } \\
\text { hissediyorum. }\end{array}$ & 219 & .71 & .97 & .83 \\
\hline $13(45)$ & $\begin{array}{l}\text { STEM uygulamalarında eleştirel düşünmeyi } \\
\text { sağlayabilirim. }\end{array}$ & 219 & .72 & .98 & .82 \\
\hline $14(46)$ & $\begin{array}{l}\text { STEM kavramlarına ve terimlerine hakim } \\
\text { olduğumu düşünüyorum. }\end{array}$ & 219 & .71 & .98 & .81 \\
\hline $15(47)$ & $\begin{array}{l}\text { STEM etkinliklerinde uyguladığım adımları } \\
\text { öğrencilerime rahatça anlatabilirim. }\end{array}$ & 219 & .69 & .98 & .79 \\
\hline $16(48)$ & $\begin{array}{l}\text { STEM uygulamaları ile ilgili planlar yaparken } \\
\text { onları hayata geçirebileceğimden eminim. }\end{array}$ & 219 & .67 & .97 & .79 \\
\hline $17(50)$ & STEM uygulamalarında kendime güvenirim. & 219 & .70 & .98 & .78 \\
\hline $18(53)$ & $\begin{array}{l}\text { STEM uygulamaları çok zor görünse de } \\
\text { yapmaya çalışırım. }\end{array}$ & 219 & .59 & .98 & .77 \\
\hline
\end{tabular}

* Eski madde numaraları parantez içinde verilmiştir.

\subsection{Doğrulayıcı Faktör Analizi ile İlgili Bulgular}

AFA ile ortaya çıkan tek boyutlu 18 maddelik yapı DFA ile tekrar test edilmiştir. Buna göre Ki-Kare değerinin $(X 2=208.37, \mathrm{P}=.000, \mathrm{~N}=219)$ anlamlı olduğu görülmüş̧tür. Uyum indeksi değerleri ise $\mathrm{RMSEA}=.05, \mathrm{NFI}=.99, \mathrm{CFI}=1.00, \mathrm{IFI}=1.00, \mathrm{RFI}=.98, \mathrm{GFI}=.90$ ve $\mathrm{SRMR}=.025$ olarak bulunmuştur. $\mathrm{Bu}$ uyum indeksi değerleri modelin iyi uyum verdiğini göstermektedir. Modele ilişkin faktör yükleri Şekil 1'de verilmiştir. 
Standardize edilmiș değerler

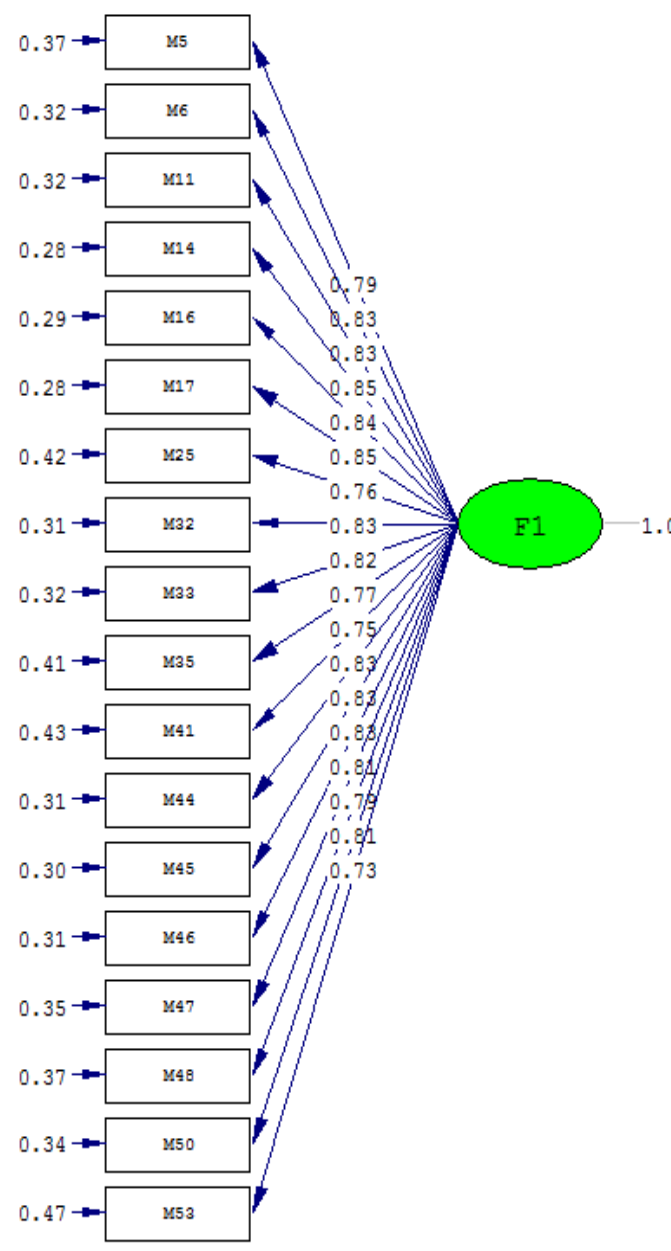

T değerleri

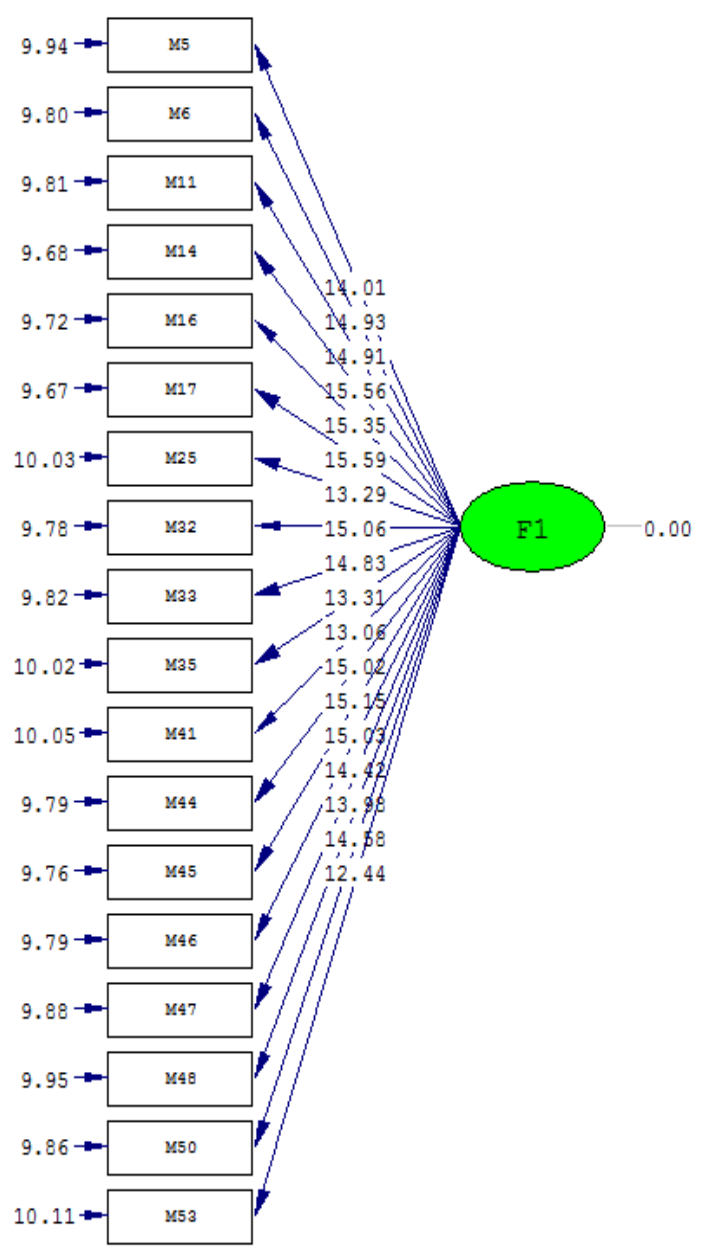

Chi-Square $=208.37, \mathrm{df}=135, \mathrm{P}$-value $=0.00005, \mathrm{RMSEA}=0.050$

Şekil 1. DFA analizi standardize edilmiş değerleri ve T-değerleri.

\section{3. Özyeterlik ve STEM Eğitimi İlişkisi}

Fen eğitimine yönelik STEM Uygulamaları Öğretmen Özyeterlik Ölçeği kullanılarak geçerlik çalışması yapılmıştır. Geçerliğe katkı sağlamak amacıyla STEM etkinliğine katılan ve katılmayan, STEM hakkında detaylı bilgisi olan ve olmayan öğrencilerin özyeterlik puanları da karşılaştırılmıştır. Bunun için iki alt problem belirlenmiştir.

1. Alt problem: STEM hakkında bilgisi olan ve olmayan öğretmen adaylarının özyeterlikleri arasında anlamlı bir fark var midir?

2. Alt problem: STEM etkinliği yapan ve yapmayan öğretmen adaylarının özyeterlikleri arasında anlamlı bir fark var mıdır?

Öğretmen adaylarının ölçekten aldığı puanların normal dağılıp dağılmadığını kontrol etmek için D'Agostino-Pearson (DP) normallik testi değerleri incelenmiştir ve verilerin normallik varsayımını karşıladığı tespit edilmiştir $\left(\mathrm{DP}_{\text {BiLGi ALAN }}=4.44 \mathrm{p}>.05, \mathrm{DP}_{\text {BiLGi ALMAYAN }}=1.47\right.$ 


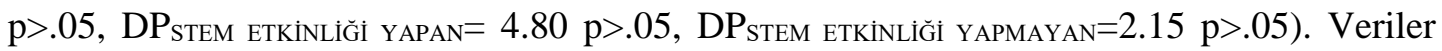
normallik varsayımını karşıladığı için Bağımsız Gruplar T-Testi yapılmıştır.

\section{Alt Probleme İlişkin Bulgular}

1. alt problem "STEM hakkında detaylı bilgisi olan ve olmayan öğretmen adaylarının özyeterlikleri arasında anlamlı bir fark var mıdır?" şeklinde ifade edilmişti. Bu problemi test etmek için 219 öğretmen adayından veri toplanmıştır. Normallik testi yapılmış ve verilerin normal dağıldığı gözlemlenmiştir $\left(D_{\text {Bilgisi oLAN }}=4.44 \mathrm{p}>0.05\right.$, DP Bilgisi OLMAYAN $=1.47$ $\mathrm{p}>0.05)$. Bu nedenle verilere parametrik bir test olan Bağımsız Gruplar T-Testi yapılmıştır. Yapılan Bağımsız Gruplar T-Testi sonuçlarına bakıldığında STEM hakkında bilgi sahibi olan öğretmen adaylarının özyeterlikleri ile STEM hakkında bilgi sahibi olmayan öğretmen adaylarının özyeterlikleri arasında anlamlı bir fark bulunmuştur $\left(\mathrm{t}_{217}=6.57, \mathrm{p}<0.05\right)$ (Çizelge $3)$.

Çizelge 3. Birinci alt probleme ilişkin bulgular.

\begin{tabular}{lllllll}
\hline STEM BÍLGISI & N & Ss & Ort. & t & df & p \\
\hline STEM Hakkında Bilgi Sahibiyim & 174 & 13.73 & 64.38 & \multirow{2}{*}{6.57} & 217 & .000 \\
STEM Hakkında Bilgi Sahibi Değilim & 45 & 17.65 & 48.33 & & & \\
\hline
\end{tabular}

\section{Alt Probleme İlişkin Bulgular}

2. alt problem "STEM etkinliği yapan ve yapmayan öğretmen adaylarının özyeterlikleri arasında anlamlı bir fark var mıdır?" şeklinde ifade edilmişti. Bu problemi test etmek için 219 öğretmen adayından veri toplanmıştır. Normallik testi yapılmış ve verilerin normal dağıldığ1 gözlemlenmiştir (DP ETKinLiK YAPAN $=4.80$ p >0.05, DP ETKINLiK YAPMAYAN $=2.15$ $\mathrm{p}>0.05)$. Bu yüzden verilere Bağımsız Gruplar T-Testi yapılmıştır. Yapılan Bağımsız Gruplar T-Testi soncuna göre STEM etkinliği yapan öğretmen adaylarının özyeterlikleri ile STEM etkinliği yapmayan öğretmen adaylarının özyeterlikleri arasında anlamlı bir fark bulunmuştur $\left(\mathrm{t}_{217}=10.21, \mathrm{p}<0.05\right)($ Çizelge 4$)$.

Çizelge 4. İkinci Alt Probleme İlişkin Bulgular.

\begin{tabular}{lllllll}
\hline \multicolumn{1}{c}{ STEM ETKİNLİĞ̇ } & N & Ss & Ort. & t & df & p \\
\hline STEM ile İlgili Etkinlik Yaptım & 136 & 12.29 & 68.17 & \multirow{2}{*}{10.21} & 217 & .000 \\
STEM ile İlgili Etkinlik Yapmadım & 83 & 14.44 & 49.47 & & & \\
\hline
\end{tabular}

\section{Tartışma ve Sonuç}

$\mathrm{Bu}$ bölümde araştırma sonuçlarının yorumu ve tartışması yapılmıştır. Bu çalışmanın temel amac1, Fen eğitiminde kullanmak için geliştirilen STEM Uygulamaları Öğretmen Özyeterlik Ölçeği 'nin geçerlik ve güvenirliğini belirlemektir. Bu amaçla, elde edilen araştırma bulguları aşağıda tartışılmıştır.

Alanyazında yeni bir yaklaşım olarak sayılabilecek STEM yaklaşımı Fen, Teknoloji, Matematik ve Mühendislik alanlarının iç içe olduğu bir yaklaşımdır. Bu yaklaşımla ilgili 
çalışmalar genellikle ilkokul, ortaokul ve lise öğrencileriyle yapılan, uygulamaya dayalı olan çalışmalardır. Literatür taraması yapıldığında ülkemizde STEM özyeterliğine dair herhangi bir çalışmaya rastlanamamıştır. Oysaki STEM özyeterliği öğretmen ve öğretmen adayları için oldukça önemlidir. STEM özyeterliği belirlenmeyen öğretmen ve öğretmen adaylarına STEM yaklaşımı uygulatmak doğru olmayacaktır.

Bu çalışmanın amacı ise STEM Uygulamaları Öğretmen Özyeterlik Ölçeği geliştirip, bu ölçeği öğretmen ve öğretmen adaylarının özyeterliklerini ölçmek için kullanmaktır. Bu nedenle bu ölçek için 55 madde oluşturulmuş ve gerekli analizler yapıldıktan sonra madde sayıs1 18'e düşürülmüştür. Geliştirilen ölçekten madde atılmasının sebebi ise binişik maddeler olmasidır.

Bu çalışmada, ölçeğin Cronbach Alpha iç tutarlık katsayısı .97 olarak hesaplanmıştır. Ölçeğe açımlayıcı faktör analizi uygulanmış ve örneklem büyüklüğünün uygunluğu KMO ve Barlett istatistiği ile onaylanmıştır $(\mathrm{KMO}=.98, x 2=208.3, \mathrm{p}=.000)$. Açımlayıcı faktör analizi sonucu ölçek ile ilgili tek alt faktöre ulaşılmıştır. Bunun nedeni ise özyeterlik ölçeğinin maddelerinin birbirine benzemesiyle ilişkilidir.

Açımlayıcı faktör analizine ilişkin modelin uygunluğunu test etmek içinse doğrulayıcı faktör analizi uygulanmıştır. Doğrulayıcı faktör analizinde uygulanan RMSEA, CFI, GFI ve $x 2$ katsayıları, açımlayıcı faktör analizinden elde edilen sonuçların iyi düzeyde olduğunu doğrular niteliktedir. Araştırma sonucunda; geliştirilen ölçekte başta 55 madde bulunurken daha sonra bu madde sayısı gerekli analizlerle 18'e düşürülmüştür. Geliştirilen ölçek tek alt boyuttan oluşmaktadır. Güvenirlik ve geçerlik katsayıları ise oldukça yüksek bulunmuştur.

Ayrıca geçerlik çalışmasına katkı sağlamak amacıyla STEM hakkında detaylı bilgisi olan ve olmayan; STEM ile ilgili etkinliğe katılan ve katılmayan öğretmen adaylarının özyeterlik puanları da karşılaştırılmıştır. Yapılan analizler sonucunda STEM hakkında detaylı bilgisi olan öğretmen adayları ile bilgisi olmayan öğretmen adaylarının özyeterlikleri arasında anlamlı bir fark bulunmuştur. Yine aynı şekilde STEM ile ilgili etkinlik yapan öğretmen adayları ile STEM ile ilgili etkinlik yapmayan öğretmen adaylarının özyeterlikleri arasında da anlamlı bir farka ulaşılmıştır. Bu sonuçlar ölçeğin geçerliğine katkı sağlamaktadır.

Analiz sonuçlarına bakıldığında öğretmen adaylarının STEM hakkında özyeterlikleri olması için ya STEM hakkında detaylı bir bilgiye sahip olmaları ya da STEM ile ilgili etkinlik yapmış olmaları gerekmektedir. Bu nedenle STEM ile ilgili bir çalışma yapılmadan önce ögretmen adaylarına STEM ile ilgili ön bilgi vermek veya STEM ile ilgili etkinlik yaptırmak daha iyi olacaktır. Yapılan çalışmalar sonucunda hazırlanan STEM Uygulamaları Öğretmen Özyeterlik Ölçeği ’nin Fen eğitimine katkı sağlayacağı düşünülmüştür. 


\section{KAYNAKLAR}

AKGÜNDÜZ, D., AYDENİZ, M., ÇAKMAKÇI G., ÇAVAŞ B., ÇORLU, M. S., ÖNER, T. \& ÖZDEMİR, S. (2015). STEM Eğitimi Türkiye Raporu: Günün Modası mı Yoksa Gereksinim mi? İstanbul: Scala Basım Yayın, 10-38.

AKKOYUNLU, B., FEZA, O. \& AYSUN, U. (2005). Bilgisayar Öğretmenleri İçin Bilgisayar Öğretmenliği Özyeterlik Ölçeği Geliştirme Çalışması, Hacettepe Üniversitesi Eğitim Fakültesi Dergisi, 29, 1-8.

AYDENIZ M. (2017). Eğitim Sistemimiz ve 21. Yüzyıl Hayalimiz: 2045 Hedeflerine İlerlerken, Türkiye İçin STEM Odaklı Ekonomik Bir Yol Haritası, University of Tennessee, Knoxwille.

BANDURA, A. (1977). Self Efficacy: Toward a Unifying Theory of Behavioral Change, Psycological Review, 84, 191-215.

BANDURA, A. (1997). Self-Efficacy: The Exercise of Control. New York:W. H. Freeman and Company.

BÜYÜKÖZTÜRK, Ş. (2002). Faktör Analizi: Temel Kavramlar ve Ölçek Geliştirmede Kullanımı, Kuram ve Uygulamada Eğitim Yönetimi, 32, 470-483.

BÜYÜKÖZTÜRK, Ş. (2004). Veri Analizi El Kitabı, Ankara: Pegem Yayıncılık.

BÜYÜKÖZTÜRK, Ş. (2017). Sosyal Bilimler İçin Veri Analizi El Kitabı: Araştırma Deseni, SPSS Uygulamaları ve Yorum, Ankara: Pegem Atıf İndeksi, 4. Baskı.

DOLAPCİ, S. (2013). Öğretmen Adaylarının Öz Yeterlilik Algıları ve Kaynaştırma Eğitimine Bakış Açıları. Yüksek Lisans Tezi, İzmir.

ERGIN, Y. D. (1995). Ölçeklerde Geçerlik ve Güvenirlik, M. Ü. Atatürk Eğitim Fakültesi Ĕgitim Bilimleri Dergisi, 7, 125-148.

EROĞLU, S. \& BEKTAŞ, O. (2016). STEM Eğitimi almış Fen Bilimleri Öğretmenlerinin STEM Temelli Ders Etkinlikleri Hakkında Görüşleri, Eğitimde Nitel Araştırmalar Dergisi, 4 (3), 43-67.

GENCER, A. S. (2015). Fen Eğitiminde Bilim ve Mühendislik Uygulamas1: Fırıldak Etkinliği, Araştırma Temelli Etkinlik Dergisi, 5 (1), 1-19.

GÜROL, A., ALTUNBAŞ, S. \& KARAASLAN, N. (2010). Öğretmen Adaylarının Özyeterlik İnançları ve Epistemolojik İnançları Üzerine Bir Çalışma, e-Journal of New World Sciences Academy, 5 (3), 1395-1404.

MİLLI EĞİTìM BAKANLIĞI. (2018). Fen Bilimleri Dersi Öğretim Programı. (Online: http://mufredat.meb.gov.tr/ProgramDetay.aspx?PID=325). 29.04.2018 tarihinde erişildi.

NAKİ, M. (2003). Pazarlama Araştırmaları Teknikler ve (SPSS Destekli) Uygulamalar, Ankara: Seçkin Yayıncılık.

ÖZÇELIK, A. \& AKGÜNDÜZ D. (2017). Üstün/Özel Yetenekli Öğrencilerle Yapılan Okul Dış1 STEM Eğitiminin Değerlendirilmesi, Trakya Üniversitesi Eğitim Fakültesi Dergisi,2 (8), 334-351. 
ÖZEN, Y. \& GÜL, A. (2007). Sosyal ve Eğitim Bilimleri Araştırmalarında Evren- Örneklem Sorunu, KKEFD/JOKKEF, 15, 395-422.

SEFEROĞLU, S. S. \& AKBIYIK, C. (2005). İlköğretim Öğretmenlerinin Bilgisayara Yönelik Öz-yeterlik Algıları Üzerine Bir Çalışma, Eğitim Araştırmaları-Eurasian Journal of Educational Research, 1, 89-101.

SİPAHİ, B.,YURTKORU, E. S. \& ÇİNKO, M. (2008). Sosyal Bilimlerde SPSS ile Veri Analizi, İstanbul: Beta Yayıncilık.

THOMAS, T. A. (2014). Elementary Teachers' Receptivity to Integrated Science, Technology, Engineering and Mathematics (STEM) Education in the Elementary Grades, University of Nevada.

TUNÇ ALPAK, G. (2018). Yaşam Boyu Öğrenme ve Bireysel Yenilikçilik. Doktora Semineri, Aydın.

WANG, H. (2012). A new era of science education: science teachers' perceptions and classroom practices of science, technology, engineering and mathematics (STEM) integration. (Doctoral Dissertation).

YILDIRIM, P. (2017). Fen, Teknoloji, Mühendislik ve Matematik (STEM) Entegrasyonuna İlişkin Nitel Bir Çalışma, Erzurum, 31-55.

YÜKSEL, K. (2010). Rehber Öğretmen Adaylarının Özel Alan ve Özyeterlik Algılart. Yüksek Lisans Tezi, Anadolu Üniversitesi Eğitim Bilimleri Enstitüsü, Eskişehir. 